HASAN ÜNDER

Forum Pedagogiczne

Ankara University

2016/2 cz. 1

Ankara (Turkey)

Received: 30.03 .2016

Accepted: 24.05.2016

DOI: $10.21697 /$ fp.2016.2.20

\title{
THE DEETHICIZATION OF LIFE AND RESTRICTING THE MORAL EDUCATION TO A NECESSARY AND PRACTICABLE MINIMUM
}

\begin{abstract}
The present article describes the current growth in ethicisation of numerous aspects of life and points out parallels between this trend and the situation in societies regulated by religious norms. The paper lists and discusses possible reasons why this tendency has appeared and concentrates on its negative aspects. Consequently, the author proposes deethicization or limiting moral education as a more realistic, feasible and advantegous strategy.
\end{abstract}

Keywords: deethicization, ethicisation, virtues, utilitarianism.

In applied ethics handbooks or encyclopedias such interesting entries as space ethics, food ethics, sport ethics, archeological ethics, computer ethics, population ethics, etc. can be found. (see, for example, Skorupski 2010; Callahan, Singer and Chadwick 2012). If this trend continues, we can predict that in the near future all spheres of human acting, doing and making will be ethicized or moralized to such extent that even the most unimportant jests and mimics may be viewed as moral or immoral.

This expansionist trend in ethics reminds us of the domination of religions over life as it has been the case in theocracies. As is well known, religions (especially revealed religions, or Judeo-Christian-Islamic tradition) try to regulate human actions according to the rules derived from sacred texts and from the behaviour of the important figures (i.e., prophets, companions, etc.) in religious tradition. The more a religious tradition develops the more its restrictions on personal choice expands. It regulates even the way of drinking water, laughing, looking, dressing hair and trimming moustache etc. The result is a life surrounded and dominated by rules believed to be sacred and there is very little room for personal choices left.

In the divine command theories of ethics there is no difference between religious obligations and ethical obligations. They define right action as commanded or approved by God and wrong action as prohibited by God. But applying non-religious ethical theories such as utilitarianism, Kantian ethics and virtue ethics 
to all spheres of life is not much different from religionisation. In moralization individual conscience replaces all-seeing God; wrongs or vices replace sins; moral obligations replace religious obligations. So non-religious ethics can be regarded as a secular substitute for religion and ethicisation as a secular version of enchantment of the world.

A life fully moralized, surrounded and dominated by ethical rules seems to me very gloomy, because what we ought to do in any given situation has been determined by moral rules and a very narrow area, if any, is left for personal choices and projects.

\section{What is the motivation of ethicisation?}

I think there are two main and interdependent reasons for this. One of them is the need for re-enchantment of the world and human life. As Weber (1946, p. 139) pointed out, intellectualization and rationalization wiped out the mysterious forces posited by myth, magic, tradition, religion and with them the unity and sacred sense of the world and human action, which means the disenchantment of the world. According to him, modernity resulted in autonomous value spheres (truth, knowledge, culture, beauty, moral goodness, utility, fairness, happiness, liberty and equality, security, eroticism) that regulates such spheres of life as economy, politics, art, religion, science etc. by their own rules. Religious and ethical values are no more dominant than other values. In the course of modernization most areas of human action have become profane although Weber calls the values of different spheres of life their own gods.

The other reason is the need to direct or channel human activities to cure and prevent some problems or evils caused by human beings. Today, the most cited human-induced problems (in religious language we can call them "moral evils") are environmental pollution, violence, vandalism, drug and alcohol abuse or whatever we perceive as a problem. The cure and solution of such problems require to redirect people's values, motivations, beliefs and behaviour. In order to do this, undesirable ones should be restricted and desirable ones promoted.

Given the weakness of religious beliefs in our secular age and the unreliability of other methods we will point out below, the best candidate to solve problems is ethics or morality. Thus, ethics is invoked as a cure.

Ethics requires giving value to the object of action and in relation to the value of the object, to the action itself. Giving value to the objects and action is a re-enchantment of the world disenchanted by modern science and secularization. We can exemplify this in the context of environmental philosophy. As is known, since 1970 s such environmental problems as pollution, global warming, endangered species etc. increasingly came to the fore and a lot of literature have been accumulated on this subject. Contrary to those who saw the solution of the environmental problems in environmental science and technology, some philosophers saw the 
roots of the problems in beliefs and value systems. Some identified the source of the problem as Western Christianity (White 1967) or anthropocentric value theory (Routley 1973; Callicott) or disenchanted mechanical worldview (Rodman 1975). They attempted to develop a non-anthropocentric value theory. Those like Tom Regan who draws on right theories extending rights to mammals or Peter Singer who draws on utilitarianism argued that suffering of the animals must be taken into account in the Benthamian hedonic calculus.

To justify environmental preservation non-anthropocentrists have made much effort to posit intrinsic value in natural things (in ecosystems, in species, in individual things). They reasoned that if we can demonstrate that nature has an intrinsic value, then natural things will have dignity and be worthy of our respect; because, as Kant (2011, p. 97-99) pointed out, things that have inner worth have dignity and are priceless. This attribution of intrinsic value or rights to natural things is a kind of reenchantment, because this saturates them with sanctity. And just as rights are what make human beings immune from being used as instruments, natural things will be immune from irresponsible use by humans too.

\section{Where does the attraction of ethicisation come from?}

I have stated that the main motive was to regulate human behaviour so that some problems originating from human attitudes could be cured or prevented. But there are methods other than ethics to channel human behaviour and choices. Governments use economic incentives, legal arrangements etc. In my opinion what makes ethicisation attractive is the character of the sanctions of ethical rules. While the sanctions of non-ethical methods are external and need an outside controller, the sanction of ethical rules is within an individual. For example, in order to punish someone who breaks the law (or who sins), the action must be identified by an external agent first, but if someone who has internalized moral rules breaks them he or she will detect them himself or herself by introspection (of all-seeing self) just as in religion nothing remains undetected by the all-seeing God. And his or her conscience will give the appropriate punishment. So, as is written in front of a Police Station in Ankara, the best policeman is one's own conscience. There is no way out of it. Moreover, it is also the best prosecutor and judge. The retribution of conscience can be such unpleasant experiences as regret, guilt, remorse, distress or shame. They are the hell of ethics.

In my opinion, what makes ethicisation repulsive is that it involves these unpleasant feelings that diminish the quality of life.

\section{Criticism of ethics or morality}

1) This hell-generating aspects of morality have been criticized by many philosophers, notably by Nietzsche $(1966 ; 2006)$. According to Nietzsche, the phenomenon 
he called "slave morality" (I think it is the true morality) rejects life-affirming values and represses the life instinct. Ethics, for him, is unhealthy. Bad conscience is an illness, a self-torture. Thus, we can say that ethicisation spreads this illness, inflicts a heavy, even an unbearable burden on moral agents. The same line of criticism of the orthodox conception of morality can be seen in Bernard Williams (2011). According to him morality amounts to a kind of obsession that threatens to consume all of life and alienate us from the individual projects that give meaning to human life.

2) The demands of moral theories is also a lively topic (see, Chappell 2009). According to critics over-demanding moral theories, especially utilitarianism, are in conflict with personal self-interest (see, Cullity 2004). However, it is not specific to utilitarianism. Other ethical theories (Kantian ethics, virtue ethics and contractarianism) are also extremely demanding. Treating people as ends in themselves obliges one to help the people in need and there are millions of them. Besides, ethical theories treat many character traits as moral virtues. Although they are desirable, some of them, like generosity etc. are not moral virtues from the moral point of view; they are at most instruments for acting according to moral virtues. (Chappell)

We can add some more criticism:

3) There are also criticisms that ethical theories emphasize other-regarding virtues and neglect self-regarding ones. As Stocker (2008) points out, they do not credit the agent's self-concern and personal projects with the importance they have; what is wrong with these theories is not neglecting self-regarding virtues (because they are not moral virtues), but leaving little room for them.

4) In ethicisation ethics has been instrumentalized. Ethical theories (except deontological theories) already have seen ethics as an instrument for attaining some goods such as happiness, environmental integrity etc. However, the use of ethics to solve human-induced problems instrumentalizes all ethics, deontological or not. And this instrumentalization diminishes the value and dignity of ethics. If we uselessly appeal to ethics, it loses its efficiency and sanctity.

5) Most importantly, the more the range of a moralizing behaviour expands the more will hypocrisy increase. This is because if we do not denature human beings through a strict upbringing, many rules will translate into a lot of transgression. To avoid guilt caused by breaching the rules, the agents will develop some defense mechanism.

\section{A proposal}

What I defend is not immoralism (the view that when the demands of morality are in conflict with our desires we must forget morality) or ethical nihilism (the view that morality is simply a kind of make-believe, a complex set of rules and recommendations that represent nothing real) or amoralism (the view that let us live beyond, or indifferent to, morality). I will outline what I defend as follows. 
Firstly, what I understand by ethics is a realist deontology. I believe that certain desires and acts are right or wrong independently of their consequences. From deontological point of view, consequentialist ethical theories are not related to ethics or morality. They are at most prudential rules to obtain a desired end. For example, if killing an innocent person - whether we treat it as an act or a rulewill bring about happiness we can, and even ought to, perform that act, though it is contrary to our ethical intuitions (classical example against utilitarianism). Moreover, desirability of the ends - for example, happiness or pleasure or eudaimonia) are controversial. Contractarianism is also wrong since it makes right and wrong dependable and thus makes them relative to the always changeable people's conventions. If a moral principle is to have an authority it must be real, that is, independent of human beings, even of God. There is of course the problem of how we can get to know these principles. Regarding this problem we can point to many sources of knowledge. We can intuit such principles by our moral sense, or practical reason or revelation etc.

Secondly, we need to minimize ethical obligations. Ethics defined as rational answers to the question "how should we live?" is too broad. It includes living within a political body, in the family, in peer groups, in workplace, on holiday etc. Almost all education is related to that question. Traditional ethical theories are full of character traits or virtues that are, I think, non-moral. Moralists included all character traits that they favoured as virtues into their moral theories. For example, Aristotle's virtues such as courage, generosity and temperance are desirable or advisable character traits of an ideal human beings. Of course, they make a person a better human being, but they are not directly moral virtues. Their opposites (vices) may be bad character traits but a person without these virtues can well be a moral person. They are not virtues like honesty or truthfulness are. They are rather like Kant's imperfect duties, and lacking in them "is not in itself culpability (Kant 1999, p. 521)." Besides, what Kant called duties to oneself are not moral duties. This is because duties are categorical and must be fulfilled, whereas alleged duties to oneself, perfect or imperfect, may not be fulfilled. As Williams (2011, p. 198) noted they may be "agreeable or worthwhile or a good idea to do, without one's being required to do them."

Thirdly, we must expand the permissible or morally indifferent range of action and choice against the forbidden and the obligatory. The forbidding and obliging rules of ethical theories (which are in the form of "do" and "do not") impose restrictions on personal choices and narrow the range of permissible actions. The aim should be to expand the permissible (i.e. morally indifferent) range of action. This will also diminish the burden of conscience.

Of course this requires a minimal deontological morality such as the ethical ones of the Ten Commandments. (I exclude the religious commandments that pertain to human-God relationship and ban the worship of other gods, graving images or work during Sabbath). "Honour your father and your mother", "do not murder", 
"do not steal", "do not give false testimony" or "do not deceive people intentionally" and "do not covet your neighbour's house". Even they can be simplified as "respect for persons" (their life, freedom, health, pleasure) particularly for those with whom we have primary relationships. I can add to these - with restriction- respect for all living and non-living things, that is ahimsa of the Indians ("do not harm any living things") in a way that does not exclude using them when necessary.

However, even the principle of the respect for persons is too demanding since it requires helping the ones in need. This single duty can consume one's life. Helping our neighbours and the people in need, especially the vulnerable ones, is our duty. This duty is on the shoulders of individuals if there is no collective agent to help them (and in my opinion, this duty comes from the times when there was no such agency). In order to alleviate the burden of ethical agents' duties they can and must be transferred to collectivity, that is, political organization or state. Welfare states and socialist states have assumed the responsibility for such people. Likewise, environmental protection, helping citizens from foreign states etc. can be transferred to political organizations, whether they are national, multinational or international. Again, the traditional virtue "justice" can be a property of social organization.

This specification of morality has some advantages. Firstly, these ethical principles seem to be universal in the sense that they are accepted by all people and cultures. I believe they have been discovered or intuited by such leading thinkers, religious leaders or philosophers as Hebrew prophets, Buddha, Socrates and Confucius in the Axial Age. Secondly, morality defined by these rules exclude many non-moral values or virtues. These commandments do not include self-regarding virtues because they are not moral virtues. They are overriding almost in all situations where there is a conflict between different values. Thirdly, if we limit ethics to an area that is really ethical, moral education becomes simple, even unnecessary, because it can be learned in family and in a society organized and maintained on the basis of such principles.

Limiting ethical duties does not amount to irresponsibility. There are non-ethical values or goods. The good things do not consist of ethical values (integrity, truthfulness, respect). There are other human goods such as religion (piety), politics (equality, justice, social responsibility, citizenship, tolerance), aesthetics (beauty, ugliness), economics (productivity, industriousness), intellect (knowledge, truth), hedonism desirability (eroticism, pleasure), etc. These values can be used to fulfill the aims that many applied ethics intended to realize. For example, we can preserve natural environment for aesthetical or religious or intellectual or economical reasons.

\section{References}

Bernard W. (2011). Ethics and the Limits of Philosophy. Routledge.

Callahan D., Singer P., Chadwick R. (eds.) (2012). Encyclopedia of Applied Ethics. Academic Press. 
Callicott J.B. (1984). Non-Anthropocentric Value Theory and Environmental Ethics. "American Philosophical Quarterly", vol. 21, No. 4.

Chappell T. (2009). The Problem of Moral Demandingness. Palgrave Macmillan.

Cullity G. (2004). The Moral Demands of Affluence. Oxford University Press.

Darwall S. (2010). Morality and its critics. In: J. Skorupski (ed.). Routledge Companion to Ethics. Routledge.

Eliot R. (1992). Intrinsic Value, Environmental Obligation and Naturalness. "The Monist", Vol. 75, Issue 2.

Jamieson D. (2003). Values in Nature. In: R.G. Frey, Ch.H. Wellman (eds). A companion to applied ethics. Blackwell.

Kant I. (1999). Metaphysics of Morals. In: I. Kant. Practical Philosophy, trans. by M.J. Gregor. Cambridge University Press.

Kant I. (2011). Groundwork of the Metaphysics of Morals. A German-English edition Immanuel Kant, Mary Gregor, Jens Timmermann. CUP, p. 97-99.

Nietzsche F. (1966). Beyond Good and Evil, trans. by W. Kaufmann. Vintage Books. Nietzsche F. (2006). On the Genealogy of Morality, trans. by C. Diethe. Cambridge University Press.

Rodman J. (1975). On the Human Questions. "Inquiry”, vol. 18, pp. 27-66.

Skorupski J. (ed.) (2010). The Routledge Companion to Ethics. Routledge.

Stocker M. (2008). Shame and Guilt. In: P. Bloomfield (ed.). Morality and Selfinterest. Oxford University Press.

Weber M. (1946). From Max Weber: Essays in Sociology, trans. by H.H. Gerth, C.W. Mills. Oxford University Press.

\section{DEETYZACJA ŻYCIA I OGRANICZENIE WYCHOWANIA MORALNEGO DO NIEZBĘDNEGO I WYKONALNEGO MINIMUM}

Streszczenie: W artykule zwrócono uwagę na nasilające się zjawisko etycyzacji zachodzące w licznych sferach życia codziennego. Prześledzono je zwłaszcza w odniesieniu do społeczeństw, w których przepisy religijne odgrywają nadrzędną rolę. Wyszczególnione i omówione zostały możliwe przyczyny pojawienia się tego trendu oraz jego negatywne konsekwencje dla życia zbiorowego i indywidualnego. Na tej podstawie autor postuluje deetycyzację, czyli ograniczenie wychowania moralnego do niezbędnego i wykonalnego minimum jako strategię bardziej realistyczną i przynoszącą więcej korzyści.

Słowa kluczowe: etycyzacja, deetycyzacja, cnoty, utylitarianizm.

Hasan Ünder - a professor of pedagogy at Ankara University (Turkey). His main areas of interest include: philosophy of upbringing, ecological education, theory of moral upbringing. E-mail address: under@education.ankara.tr. 